\title{
THE UNITED NATIONS ENVIRONMENT PROGRAMME (UNEP) - AN ASSESSMENT
}

\author{
Said Mahmoudi*
}

\section{INTRODUCTION}

The protection of the environment at national, regional and international levels is a relatively new concern. Although one may find national legislation or international agreements from the turn of the century with some bearing on the environment, they are not normally considered as 'environmental' legal acts or documents since their adoption was very often instigated by considerations other than care for the environment and its components. ${ }^{1}$ Not until the end of the 1950s and the beginning of the 1960 s were the effects of intensive post-war reconstruction and the pressure of hightempo full-production policies on the environment seriously considered, and only then did the concern for the status of the environment find concrete expression in the form of legal rules and principles. That is why very many of the legal measures specifically adopted with the main objective of protecting the environment originated only since the middle of the $1960 \mathrm{~s}$.

Having this background in mind, it is easy to understand why 'protection of the environment' - one of the most debated subjects of our time was not mentioned in the Charter of the United Nations and did not appear in the UN's agenda until the late 1960s. ${ }^{2}$ With regard to the bitter experience of the two World Wars, the main task of the UN was expected to be to contain the use of force against the territorial integrity of the member states

\footnotetext{
* Professor of International Law, University of Stockholm.

${ }^{1}$ One often-repeated example is the 1901 Convention for the Protection of Birds Useful to Agriculture. Even the title of the convention clearly shows that the main objective is not to protect the birds as a part of biological diversity, but to use them in an economic activity. A. KIsS, Droit international de l'environnement, Pedone, 1989, p. 5.

${ }^{2}$ In this respect, the UN Charter is comparable with the 1957 Treaty of Rome, which established the European Economic Community (EEC). The word 'environment' was not mentioned in that Convention either. However, the EEC, like the UN, used to rely on its implied powers for environmental legislation.
} 
and to secure respect for human rights. To fulfil this task, the Charter provided the UN with a number of broadly formulated competencies which would permit the Organisation to act in virtually any field of human wellbeing. In this respect, mention should particularly be made of the Economic and Social Council (ECOSOC) which, because of its mandate and powers, could easily involve itself in environmental issues, and act as a catalyst by making recommendations to UN members, the General Assembly and specialised agencies. ${ }^{3}$ This was how the UN, while lacking any expressed mandate, could start directly addressing environmental issues towards the end of the $1960 \mathrm{~s}^{4}$

The first major and concrete step was taken in 1972 when the UN Conference on the Human Environment (the Stockholm Conference) was convened. The Stockholm Conference is generally considered as the starting point for international environmental law, a conference which "drew attention to the right of human beings to an environment of quality", 5 and which "marked the culmination of efforts to place the protection of the biosphere on the official agenda of international policy and law". 6 One of the main results of the Stockholm Conference was the decision to recommend launching the United Nations Environment Programme, UNEP, a specific machinery within the UN system to deal exclusively with environmental issues. However, UN involvement in environmental issues has not been limited to UNEP. It has, through its specialised agencies and other affiliated organs, played an important role in the protection of the environment. ${ }^{7}$ In addition, the UN made invaluable contributions to the development of international environmental law through its regional commissions. ${ }^{8}$

\footnotetext{
${ }^{3}$ UN Charter, Article 63.

${ }^{4}$ Cf P. BIRNIE, 'The UN and the Environment', in: RoberTs \& KINGSBURY, eds., United Nations, Divided World: The UN's Roles in International Relations (Clarendon Press, 1993) p. 335. BIRNIE refers to the doctrine of implied powers and effective interpretation, and opines that the powers of the UN were expressed in such comprehensive terms that an extensive interpretation would permit the Organisation to deal with environmental issues. Even in the EEC, environmental measures were adopted despite any explicit Community competence in this area. The situation there, however, changed in 1987 when, through the Single European Act, the Community received specific legislative competence in the field of environment.

${ }^{5}$ BIRNIE, p. 328.

${ }^{6}$ L.K. CALDWELL, International Environmental Policy (Duke University Press 1990) p. 55.

${ }^{7}$ CALDWELl names those specialised and affiliated agencies which have been involved in environmental questions. They are: FAO, GATT, IAEA, ICAO, ILO, IMO, ITU, UNESCO, WHO and WMO. Ibid., pp. 339-340.

${ }^{8}$ There are five UN regional commissions: Economic and Social Commission for Asia and the Pacific; Economic Commission for Africa; Economic Commission for Europe; Economic Commission for Latin America; Economic Commission for Western Asia.
} 
The role of the Economic Commission for Europe (ECE) should be particularly underlined here. ${ }^{9}$

The role of the United Nations in general and the work of any of its organs or specialised agencies with respect to the environment could be subject of a separate study. This paper is mainly concerned with the UN's principal environmental establishment, UNEP. Thus, after a short account of the genesis of UNEP, its structure and its legal status, its contribution to the development of international environmental law and its potential for global environmental protection will be briefly commented on.

\section{THE GENESIS OF UNEP}

The establishment of UNEP should be seen in the light of the events which led to the convocation of the Stockholm Conference in 1972, the circumstances governing that Conference and the attitude of states toward the issues of environment and development.

Although national and some regional approaches to environmental problems, particularly through the efforts of non-governmental organisations, had been initiated in several countries and regions during the 1960s, the need for internationally concerted steps and more comprehensive policies was greatly felt. Seriously concerned about large-scale environmental problems and fully aware of the need for international action, Sweden in December 1967 submitted to the General Assembly a proposal for the convocation of a UN Conference on this issue. The Swedish proposal was referred to ECOSOC, which on 30 July 1968 adopted a resolution requesting the UN to convene a Conference on the Human Environment. ${ }^{10}$ The General Assembly agreed, and unanimously decided on 3 December the same year to convene the first UN Conference on the Human Environment in Stockholm in June 1972. ${ }^{11}$ A preparatory commission was established at the same time as a range of studies on important relevant problems was initiated. An important report by the UN Secretary-General in May 1969 elucidated the activities and programmes of UN bodies relative to the

\footnotetext{
9 The adoption of the 1979 Geneva Convention on Long-Range Transboundary Air Pollution (18 ILM p. 1442) and the 1991 Convention on Environmental Impact Assessment in a Transboundary Context (30 ILM p. 800), e.g., was due to the efforts of the ECE.

${ }^{10}$ ECOSOC Resolution 1346 (XLV).

${ }^{11}$ UNGA Resolution 2398 (XXIII).
} 
human environment. ${ }^{12}$ The report clearly demonstrated that environmental issues were being dealt with sectorally, ${ }^{13}$ a situation which the Stockholm Conference was expected to change through its holistic approach. The prime objective of the Conference, as spelled out in the General Assembly resolution, was:

"to provide a framework for comprehensive consideration within the United Nations of the problems of the human environment in order to focus the attention of Governments and public opinion on the importance and urgency of this question and also to identify those aspects of it that can only or best be solved through international co-operation and agreement." 14

This purely 'environmental' objective was contested by the majority of the developing states. For Sweden, as the country which had taken the initiative to the Stockholm Conference, as well as for a number of other industrialised countries which had observed the devastating effects on the environment of hasty economic development and full industrialisation, the main concern was of course environmental protection. Developing countries, on the other hand, considered the environmental movement as a threat to their development aspiration and "a colonialist conspiracy to thwart development by imposing upon them extra costs and prohibitions that developed states had not faced in the nineteenth and early twentieth centuries in implementing their pollution-generating, resource-consuming industrial revolutions." 15 To overcome this problem and reconcile the concerns for environment and development, the preparatory commission of the Stockholm Conference arranged a meeting of scholars from different disciplines at Founex, Switzerland in 1971. One of the main findings of this meeting was that environmental damage probably results not only from the development process itself, but also from lack of development. Consequently, environmental problems in developing countries could be overcome by the process of development itself. ${ }^{16}$ This finding somehow paved the way for the developing countries to come to Stockholm, albeit some with hesitation.

\footnotetext{
${ }^{12}$ Report of the Secretary-General, 'Problems of the Human Environment', UN doc. E/4667. The Secretary-General had in the previous year submitted another report to the same effect, UN doc. E/4553.

${ }^{13}$ Cf. BIRNIE, p. 340.

${ }^{14}$ UNGA Resolution 2398 (XXIII), last preambular paragraph.

${ }^{15}$ BIRNIE, p. 338. KISS quotes a developing country delegate in the Conference as saying "let me die polluted". KISS, Droit, p. 36.

${ }^{16}$ For a detailed account of the Founex meeting, see CALDWELl, p. 52; BIRNIE, p. 338.
} 
The whole work of the Stockholm Conference and the results achieved were marked by the schism between the concern of the developed states for the environment and the apprehensions of the developing countries over the undesirable effect of environmental measures on the pace of development. Of the six subjects included in the Conference agenda, one dealt exclusively with development and environment. Another concerned the international organizational implications of action proposals. The Conference, which was held between 5 and 16 June 1972 with delegates from 113 states, concluded its work by adopting an Action Plan and a Declaration of Principles, and by recommending the establishment of an environmental fund and new UN machinery for administering and directing the UN environmental programme. UNEP was planned not as a specialised agency with independent powers, but rather as a small secretariat within the framework of the UN Secretariat. The Conference recommendation also provided for a fifty-four-state Governing Council for the implementation of the UN environmental programme.

On 15 December 1972, the General Assembly upon the recommendations of the Stockholm Conference adopted a Resolution under the title of institutional and financial arrangements for international environmental cooperation. ${ }^{17}$ This Resolution underscored that while the responsibility for action to protect the environment could be exercised more effectively at the national and regional level, environmental problems of broad international significance would fall within the competence of the United Nations system. It further emphasized the sectoral responsibilities of the organisations within the UN system. The Resolution then referred to the report of the SecretaryGeneral on the results of the Stockholm Conference concerning the urgent need for a permanent institutional arrangement within the United Nations system for the protection of the environment, and established UNEP, its Governing Council and Environment Fund.

The developing countries succeeded in increasing the size of the Governing Council to fifty-eight states. The four additional seats were to accommodate greater representation from Asia. The developing countries further succeeded, through UNGA Resolution 3004 (XXVII), in changing the location of UNEP from its expected site in Geneva to Nairobi, Kenya. ${ }^{18}$ The initiative for this change came from some newly independent African states and gained support among all developing countries to mark

\footnotetext{
${ }^{17}$ UNGA Resolution 2994 (XXVII). The General Assembly adopted eleven resolutions concerning the recommendations of the Stockholm Conference, Resolutions 2994 to 3604 (XXVII).

${ }^{18}$ CAlDWell, p. 69.
} 
the dissatisfaction with the fact that no UN body was located in a developing country. ${ }^{19}$ The choice of Nairobi was generally considered necessary to encourage the participation of the developing countries. It was also interpreted as a clear indication of the influential role that developing countries were going to play in UNEP. Even if politically perhaps a necessity, the location of UNEP in Nairobi definitely complicated the performance of one of its main functions: co-ordination with other UN bodies and contact with governments, environment movements and the mass media. ${ }^{20}$

Thus UNEP's Governing Council was established with the predomination of the developing countries. The UNEP Charter underscored that it should pay special attention to the situation of developing countries. ${ }^{21}$ The early manifestation of control by developing countries over the choice of site and the composition of the Governing Council was construed by several observers in the West as an indication that UNEP would become another forum for the voicing of frustrations of ex-colonial states and a new channel for development assistance. However, later developments demonstrated that these misgivings were ill-founded since developing countries soon recognised the seriousness of environmental problems and the significant role that UNEP could play as a professional body in combating these problems. ${ }^{22}$ This change of attitude among the majority of the developing countries is probably because UNEP has managed to give the international environmental movement universality, legitimacy and acceptability. ${ }^{23}$

UNEP's terms of reference as spelled out in General Assembly Resolution 2997 (XXVII) are broadly and somewhat vaguely formulated. UNEP is required, inter alia,

"to promote international co-operation in the field of the environment, and to recommend, as appropriate, policies to this end, [and] to provide general policy guidance for the direction and coordination of environmental programmes within the United Nations system. ${ }^{24}$

\footnotetext{
${ }^{19}$ The fourth paragraph of Resolution 3004 (XXVII) notes that the headquarters of the United Nations and of the specialised agencies are all located in developed states in North America and Western Europe. To apply the principle of equitable geographical distribution, the General Assembly decided, according to the last paragraph of the same Resolution, to locate the environmental secretariat in a developing country, namely, in Kenya.

${ }^{20}$ CAldwell, pp. 69-70; BiRnie, p. 343.

${ }^{21}$ UNGA Resolution 2997 (XXVII), part I, para. 2(f).

${ }^{22}$ CAldWell, p. 71.

${ }^{23}$ Ibid., p. 83.

${ }^{24}$ UNGA Resolution 2997 (XXVII), part I, para. 2(a) and (b).
} 
This rather unspecified mandate clearly excludes enforcement or supranational decision-making powers, but at the same time leaves it up to UNEP's Executive Directors to use the increasing public pressure and push for more than what a literal interpretation of its mandate may permit. ${ }^{25}$

The 1992 UN Conference on the Environment and Development at Rio de Janeiro (the Rio Conference) proposed an expansion of UNEP's mandate. According to this proposal, UNEP should concentrate on the following priority areas: strengthening its catalytic role in stimulating and promoting environmental activities and considerations throughout the UN system, promoting international co-operation in the field of environment, environmental monitoring and assessment, dissemination of environmental information, further development of international environmental law, promotion of the widest possible use of environmental impact assessments, facilitation of information exchange on environmentally sound technology and provision of training, promotion of sub-regional and regional co-operation development, providing technical, legal and institutional advice to governments, upon request, in establishing and enhancing their national legal and institutional frameworks, supporting governments in the integration of environmental aspects into their development policies, and further developing assessment and assistance in cases of environmental emergencies. ${ }^{26}$ It was also proposed that this expansion of functions were to be accompanied by an increase of expert staff and financial resources, as well as closer co-operation with UNDP and the World Bank. ${ }^{27}$

\section{UNEP'S STRUCTURE}

Both before and during the Stockholm Conference, the new UN institution for the coordination of environmental measures was conceived as a secretariat relatively small in comparison to other UN bodies. This was even enshrined in UNEP's Charter. ${ }^{28}$ UNEP as a small secretariat started

\footnotetext{
${ }^{25}$ BIRNIE points out that "[d]espite the constraint imposed on UNEP by its organisational and financial framework and terms of reference, its first two Executive Directives seized the opportunities provided by ambiguities in the latter to expand UNEP's role”. BIRNIE, pp. 347348. See also CALDWELL, p. 79.

${ }^{26}$ Agenda 21, Chapter 38, para. 22.

${ }^{27}$ Ibid., para. 23.

${ }^{28}$ UNGA Resolution 2997 (XXVII), part II, para. 1, which provided that "a small secretariat shall be established in the United Nations to serve as a focal point for environmental action and co-ordination within the United Nations system in such a way as to ensure a high degree of effective management."
} 
its work in 1973 with a staff of approximately 100 employees headed by an Executive Director and controlled by a Governing Council. The number of staff has doubled since. ${ }^{29}$ These professionals are located both a headquarters in Nairobi and in UNEP's regional offices around the world including in Geneva, Vienna, Bangkok and Mexico.

The Governing Council, as mentioned, consists of representatives of 58 states, which are not required to be members of the United Nations. They are elected by the General Assembly on the basis of equitable geographical distribution. The Council usually meets biennially in Nairobi to deliberate policy matters, issue decisions and set UNEP's agenda. ${ }^{30}$ Apart from promoting and co-ordinating international co-operation for the protection of the environment, it is obliged to receive reports from UNEP's Executive Director concerning the implementation of environmental programmes within the UN system, to keep the world environmental situation under review, to review the impact of national and international environmental measures on the developing countries, and to review and approve annually the programme of utilisation of resources of the Environment Fund. ${ }^{31}$ The Governing Council reports annually to the General Assembly through ECOSOC. ${ }^{32}$ ECOSOC thereby has the possibility to transmit its own comments on the report. One significant implication of the Council mandate is that it should ensure that UNEP keeps within the limits deliberately put on it, and concentrates on supporting the programmes of others rather than introducing its own great scheme. ${ }^{33}$

UNEP is headed by an Executive Director elected by the General Assembly on the nomination of the UN Secretary-General for a term of four years. So far, UNEP has had three Executive Directors: MAURICE STRONG (Canada), Mustafa Tolba (Egypt) and ElisabeTh Dowdeswell (Canada). The main functions of the Executive Director include: to provide substantive support to the Governing Council, to co-ordinate environmental programmes within the UN system, to advise the UN's specialised agencies on the formulation of environmental programmes, to bring to the attention of the Governing Council any matter which he/she deems to require con-

\footnotetext{
${ }^{29}$ Annual Report of the Executive Director of the United Nations Environment Programme, 1987 , p. 149.

${ }^{30}$ C.A. PETSONK, 'The Role of the United Nations Environment Programme (UNEP) in the Development of International Law', 5 American University Journal of International Law and Policy (1990) 355.

${ }^{31}$ UNGA Resolution 2997 (XXVII), part I, para. (c)-(g).

${ }^{32}$ Ibid., part I, para. 3.

${ }^{33}$ BIRNIE, p. 345.
} 
sideration, and to administer the Environment Fund. ${ }^{34}$ In performing its functions, the Executive Director is fully under the authority and policy guidance of the Governing Council.

The funding of UNEP has been insufficient and this is one reason for its restricted role. There are two sources of funding. The administrative costs of UNEP and its Governing Council are borne by the UN budget and the costs of operational programmes by the Environment Fund. ${ }^{35}$ The latter is a voluntary fund based on pledging of voluntary contributions by UN members. These have always been inadequate for UNEP to finance the environmental programmes of general interest. One observer considers that developed states have, through the inadequacy of their financial contributions, tried to ensure that UNEP does not gain the power "to interfere with industrial development, encroach on the roles of existing sectoral organisations, or seek itself to become a specialised agency". ${ }^{36}$ The initial contribution to the fund was $\$ 20$ million. It has fluctuated during the years, but UNEP has at all time lacked enough money to finance all its urgent plans. The UNEP budget for 1992-93 was \$150 million and for 1994-1995 it was $\$ 120$. The leading role that UNEP has played in recent years with respect to international co-operation concerning global environmental problems, such as depletion of the ozone layer, climate change and biological diversity, has enhanced its position. This is formally acknowledged in Agenda 21 adopted by the Rio Conference, ${ }^{37}$ and it is expected that the rich UN members would now like to increase UNEP's budget. ${ }^{38}$

\section{UNEP'S LEGAL STATUS}

The discussions which preceded the Stockholm Conference were not only about environmental problems in need of urgent international action, but also about the type of international institutional arrangement required for addressing the problem. Three options were generally suggested. One was the establishment of a new organisation outside the UN system, consisting only of those states that were responsible for causing the environ-

\footnotetext{
${ }^{34}$ UNGA Resolution 2997 (XXVII), part II, para. 2(a)-(j).

${ }^{35}$ Ibid., part II, para. 3.

${ }^{36}$ BIRNIE, p. 345.

${ }^{37}$ See supra, note 26.

${ }^{38}$ The 18th session of the UNEP governing body, which met in Nairobi in May 1995, discussed the 1996-1997 budget of UNEP. Due to world fiscal constraints the expected budget for this period will be $\$ 105$ million. See 18 International Environment Reporter (June 1995) 450.
} 
mental problems, namely the major industrialised and polluting states of the West. ${ }^{39}$ This proposal was never taken seriously since not only was it unrealistic with respect to the role the developing countries were expected to play by not committing the same mistakes as the West, ${ }^{40}$ but also it could seriously discredit the authority of the United Nations in other fields. ${ }^{41}$

The second proposal, which was tabled by UN Secretary-General U THANT, advocated a powerful new agency within the UN system, a specialised agency, with the authority to ensure that agreed measures were actually carried out. This proposal did not meet much enthusiasm either. One reason was the general attitude towards existing specialised agencies, their huge expenditures, ineffective working methods, rigidness, and poor output. The other reason was the fact that many of the specialised agencies including WMO, WHO, FAO, UNESCO and ICAO were already engaged in environmental activities, and it made no sense to remove these activities from existing specialised agencies and place them in a new agency. Even the specialised agencies themselves were strongly against the establishment of a new agency with a leading role in the field of the environment. The most important reason was that, given the nature of environmental problems at that time, it was deemed appropriate and adequate from the viewpoint of efficiency to have a limited number of states represented in the new institution with a secretariat of experts and scholars and not bureaucrats. ${ }^{42}$

The third alternative was to expand the work of the existing specialised agencies and other organs to carry the new load of environmental affairs instead of establishing a new organ. ${ }^{43}$ This was the option which was favoured by the specialised agencies. Even this option was not attractive to the states since it was generally realised that the type of international environmental policy which was looked for cut across the traditional specialities of specialised agencies. It required an overall perspective, which no specialised agency could achieve. CHAYES, in a prophetic commentary in 1972 , stated that the viable alternative would be "some form of a high level

${ }^{39}$ G. Kennan, 'To Prevent a World Wasteland: A Proposal', 48 Foreign Affairs (1970) 401.

${ }^{40}$ This theme was of great concern within the UN. The sixth preambular paragraph of UNGA Resolution 2398 (XXIII), e.g., contains "the strong hope that developing countries will, through appropriate international co-operation, derive particular benefit from the mobilisation of knowledge and experience about the problems of the human environment, enabling them, inter alia, to forestall the occurrence of many such problems".

${ }^{41}$ Cf. A. ChaYes, 'International Institutions for the Environment', in HARGrove, ed., Law, Institutions \& the Global Environment (Oceana Publications Inc., 1972) p. 5.

${ }^{42}$ Ibid., pp. 6-7.

${ }^{43}$ Ibid., p. 8. 
policy planning, co-ordination and review unit within the UN proper". ${ }^{44}$ And that is exactly what UNEP is. ${ }^{45}$

UNEP is not a specialised agency. Specialised agencies, according to the definition in Article 57 of the UN Charter, are established by intergovernmental agreements. They have wide international responsibilities, as defined in their basic instruments, in economic, social, cultural, educational, health and related fields. They are legal and autonomous entities with their own membership and organs. They are brought into relationship with the United Nations through entering into agreements with the ECOSOC. Such agreements must be approved by the General Assembly. In these agreements, the specialised agencies agree that ECOSOC co-ordinates their activities through consultation with and recommendations to such agencies and through recommendations to the General Assembly and to the members of the United Nations. ${ }^{46}$ In the agreements with ECOSOC, specialised agencies undertake to submit regular reports to the organ. ${ }^{47}$

The absolute majority of the specialised agencies either already existed at the time of the League of Nations or their establishment was foreseen by the end of World War II. ${ }^{48}$ The UN has been reluctant to establish new specialised agencies despite the need in many new areas for centralised international co-operation. Instead, it has a number of subsidiary organs including funds and programmes. These United Nations bodies have some degree of administrative autonomy, with a staff which is part of the Secretariat and a governing body which is elected by the ECOSOC or the General Assembly. They are under the control of the main organs of the

\footnotetext{
${ }^{44}$ Ibid., p. 9.

${ }^{45}$ The general views about the future institutional mechanism were described in UN doc. A/CONF. 48/11, dated 10 January 1972, under the title of "International Organisational Implications of Action Proposals". According to this document, there was agreement between states that nothing new should be set up until it was clear what needed to be done and that existing institutions could not do it. Cf. P. THACHER, 'The Role of the United Nations', in HuRrell \& Kingsbury, eds., The International Politics of the Environment (Clarendon Press, 1992) 186.

${ }^{46}$ UN Charter, Article 63.

${ }^{47}$ Ibid., Article 64.

${ }^{48}$ Six specialised agencies were already established by 1945: ITU (1865), UPU (1874), ILO (1919), FAO (1945), IMF and IBRD (1945). Three were continuations of pre-World War II institutions: UNESCO, WHO and WMO. IMCO (later IMO) is the specialised agency which was established after World War II. IAEA is not considered a specialised agency since, unlike other specialised agencies it submits its reports directly to the General Assembly and not to the ECOSOC. It can also report, when appropriate, to the Security Council. Cf. M. ElmandJRA, The United Nations System: An Analysis (Faber and Faber, 1973) 85-86, 118.
} 
UN, and normally are forced to keep within a tight budget not requiring much funding.

UNEP is a subsidiary organ ${ }^{49}$ of the General Assembly established under Article 22 of the UN Charter, as an autonomous and independent unit within the broader framework of the UN Secretariat. ${ }^{50}$ It has no independent powers and no supranational authority. ${ }^{51}$ It plays a primarily coordinative role. Unlike some specialised agencies, it cannot monitor or enforce the law. It derives its authority from the mandate which has been given to it by the General Assembly. It has so far applied an extensive interpretation of its mandate. ${ }^{52}$

The specialised agencies' resistance to UNEP's co-ordination and leadership role, shown at the time of its inception, has moderated with the passage of time. This is partly due to the growth of national concern, mainly in the developing countries, which is reflected in the work of the governing bodies of the specialised agencies. But the reluctance of the industrialised countries to establish a new specialised agency for the environment, which was strongly pointed out before the Stockholm Conference, has continued. When in 1991 the strengthening of UNEP was being discussed by the preparatory commission for the Rio Conference, one of the ideas put forward by some states was to transform UNEP into a specialised agency. However, the Conference rejected the idea. ${ }^{53}$

Given the nature of the problem and political circumstances of the time, the decision at the Stockholm Conference not to establish a new specialised agency was both understandable and prudent. However, transformation of UNEP into a specialised agency now after more than twenty years of

\footnotetext{
${ }^{49}$ The UN Charter recognises, in Article 7, only two categories of organs for the United Nations: i.e. the principal organs (General Assembly, Security Council, Economic and Social Council, Trusteeship Council, International Court of Justice, and Secretariat) and subsidiary organs, which may be established by the General Assembly (Article 22), by the Security Council (Article 29) or by ECOSOC (Article 68). However, lack of definition for subsidiary organs in the Charter seems to have given rise to controversies on whether all units established by these three principal organs shall be called subsidiary organs or some of these units can be termed as organs of e.g. the General Assembly. In the practice of the United Nations, UNCTAD, UNIDO and UNCDF are termed as organs of the General Assembly whereas UNHCR, UNDP, UNEP, UNICEF, UNITAR and some other units are categorised as subsidiary organs. For discussion, see ElmANDJRA, pp. 48-49; B. SimMA, The Charter of the United Nations: A Commentary (Oxford University Press, 1994) 196-197.

${ }^{50}$ The General Assembly has the authority according to Article 23 of the Charter to establish such subsidiary organs as it deems necessary for the performance of its functions.

${ }^{51}$ BIRNIE, p. 342.

${ }^{52}$ Its Executive Directors have seized the opportunities to expand UNEP's role. Ibid., p. 347.

${ }^{53}$ BIRNIE, p. 344.
} 
successful activity may have some advantages. The concern shown before the Stockholm Conference about the risk of policy-making paralysis in a new specialised agency with an open membership of the majority of the countries having different environmental priorities, appears now to be over.

Following over two decades of activity, UNEP now has its own working routines and a well-balanced composition of professional staff. There is, therefore, little risk that, in case of transformation into a specialised agency, it will suffer from problems related to the staffing patterns, regulations and practices of other such agencies. UNEP as a specialised agency with an autonomous legal personality, large membership and increased budget would be much better equipped to launch long-term environmental programmes. As a subsidiary organ - a programme - UNEP is dependent on voluntary contributions from states. As a specialised agency, it would have an approved budget based on proportionate contributions of all its members. ${ }^{54}$ As a subsidiary organ created by and under the authority of the General Assembly, its policies and activities are constantly examined and controlled by the Assembly. The General Assembly can indeed change its agenda, or simply dissolve it. ${ }^{55}$ As a specialised agency, it would keep its independent status while related to the United Nations.

More importantly, UNEP's independent status as a specialised agency would permit it to request, under Article 96(2) of the UN Charter, advisory opinions from the International Court of Justice on matters of principle. ${ }^{56}$ The General Assembly has indeed the power, according to Article 96(2) of the Charter, to authorise even subsidiary organs to request advisory opinions. However, such authorisation has nog yet been given. In contrast, the General Assembly, through the approval of the agreements between the specialised agencies and the ECOSOC by virtue of Article 63(1) of the Charter, has implicitly authorised these agencies to request advisory opin-

\footnotetext{
${ }^{54}$ The budget of specialised agencies and the apportionment of financial responsibility of the member states are approved by the governing bodies of these agencies. However, the General Assembly, according to Article 17(3) of the Charter "shall consider and approve any financial and budgetary arrangements with specialised agencies referred to in Article 57 and shall examine the administrative budgets of such specialised agencies with a view to making recommendations to agencies concerned".

55 SimMA, p. 196.

${ }^{56}$ In the absence of such a possibility for UNEP, a specialised agency - WHO - has recently requested the advisory opinion of the Court on the legality of the use by a state of nuclear weapons in armed conflicts, a matter which certainly has a significant environmental implication. ICJ Rep. 1993, p. 467.
} 
ions of the Hague Court. ${ }^{57}$ As a specialised agency, UNEP would most probably receive such authorisation.

\section{UNEP'S FUNCTIONS AND ACTIVITIES}

The basic functions of UNEP, as spelled out in General Assembly Resolution 2997 (XXVII), are the dissemination of information, fostering of understanding, and assistance to other agencies' programmes. ${ }^{58}$ Under this broad mandate, the Governing Council in its biennial meetings sets UNEP's agenda. The point of departure in all UNEP's activities is to build awareness of the relation between environment issues and development issues. The initial meetings of the Governing Council were strongly characterised by the political manoeuvring of each group of states to consolidate its own position. For the developing countries, development-relevant questions had priority whereas the industrialised states were basically concerned with environmental problems.

A first task of UNEP was the establishment of a global assessment programme - Earthwatch. This was a component of the Action Plan adopted by the Stockholm Conference. ${ }^{59}$ It was to include a Global Environmental Monitoring Service (GEMS) and an International Referral Service, a worldwide data network for environmental information. ${ }^{60}$ The latter later changed name to International Referral System for Sources of Environmental Information - INFOTERRA. Earthwatch's task was world-wide monitoring to detect significant changes in critical environmental conditions, to gather information, to stimulate scientific research, to evaluate and review the information and the result of the research, and to link by computer nationally held information. ${ }^{61}$ UNEP also created an International Register of Potentially Toxic Chemicals (IRPTC). Through this register, UNEP has been able to assist particularly the developing countries to establish their own chemicals information system. GEMS is a wellfunctioning service, and its activities today cover over 140 countries. INFOTERRA, in contrast, is not yet fully utilised.

\footnotetext{
${ }^{57}$ SIMMA, p. 1012. The only specialised agency which has not received authorisation is UPU. Specialised agencies which have so far used this possibility include UNESCO, WHO and IMO.

${ }^{58}$ CAlDWell, p. 74.

${ }^{59}$ Action Plan, Section C, first paragraph.

${ }^{60}$ Ibid, Recommendation 101.

${ }^{61}$ Caldwell, p. 72; BIRNIE, p. 342; Action Plan, Section C.
} 
The industrialised countries considered the establishment and proper functioning of Earthwatch as UNEP's most important and urgent task. The developing countries, relying on their numerical strength, managed in the first session of the Governing Council in 1973 to downgrade this programme to demonstrate their political power and to underline their own priorities. ${ }^{62}$ This difference of attitudes was soon replaced by a common understanding of the significance of Earthwatch, which has recently expanded considerably. The developing countries have indeed benefited most from this programme. ${ }^{63}$

As regards UNEP's co-ordinating role, the Stockholm Conference provided specifically for the establishment of the Environmental Co-ordination Board (ECB), chaired by the Executive Director and under the auspices of the United Nations Administrative Committee on Co-ordination (ACC) ${ }^{64}$ The main function of this Board was to ensure co-operation and co-ordination among all bodies concerned with the implementation of environmental programmes. ECB was soon discontinued, and its task was entrusted to ACC, which consists of the heads of the specialised agencies and other bodies under the chairmanship of the Secretary-General. As regards the environment, ACC has, pursuant to the Rio Conference, established an Inter-Agency Committee on Sustainable Development ${ }^{65}$ and another unit named Designated Officials for Environmental Matters. UNEP plays a significant role in both bodies, and acts as the secretariat for the latter. ${ }^{66} \mathrm{~A}$ concrete step within the framework of UNEP's co-ordinating function is the adoption of a programme on Awareness and Preparedness for Emergencies at the Local Level (APELL) and the establishment in 1991 of a UN Centre for Urgent Environmental Assistance. ${ }^{67}$ The purpose is to address assessment of and responses to manmade environmental emergencies, including industrial accidents.

UNEP co-sponsored a survey in 1979 of nine international financing agencies, which revealed a general absence in the agencies of systematic

\footnotetext{
${ }^{62}$ CAldwell, ibid.

${ }^{63}$ According to THACHER, the Stockholm Conference's Action Plan consisted of three functional components, namely, an assessment programme (Earthwatch), management activities, and supporting measures. He maintains that assessment functions under UNEP's Earthwatch have been well discharged by the UN system whereas the result of UNEP work with respect to management actions at the national level is less impressive. THACHER, p. 187.

${ }^{64}$ Resolution 2997 (XXVII), Part IV, para. 14.

${ }^{65}$ It consists of FAO, IAEA, IMO, UNDP, UNEP, UNESCO, WHO, WMO and the World Bank.

${ }^{66}$ Cf. BIRNIE, pp. 346-347.

${ }^{67}$ UNGA Resolution 44/224 (1989); UNEP/GC. 16/9(1991).
} 
attention to environmental impacts of different financial projects. As a result of this survey, UNEP drew up a Declaration of Environmental Policies and Procedures related to economic development. The Declaration was signed in 1980 by all major multilateral funding agencies in Europe, Latin America, Asia and Africa as well as the World Bank, FAO, UNDP, the European Community and the Organization of American States. ${ }^{68}$ Following the adoption of the Declaration, a Committee of International Development Institutions on the Environment (CIDIE) consisting of UNEP, UNDP and the above-mentioned intergovernmental financial institutions was established for which UNEP acts as secretariat.

UNEP publishes an annual report on The State of the World's Environment. By reporting in this way on environmental problems and development of protection measures at national, regional and international levels, it partially fulfils its monitoring function in general but also indirectly monitors environmental law enforcement in particular.

The priority areas of UNEP have been revised many times. Its initial programmes, adopted in the first session of the Governing Council in 1973, gave priority to the following items: human settlements; land, water and desertification; education, training, assistance and information; trade, economics and transfer of technology; oceans; conservation of nature, wildlife, and genetic resources; and energy. ${ }^{69}$ Some of these items are still on the list of UNEP's priorities while some others, e.g. energy, no longer appear on this list. At present UNEP carries out a four-pronged programme: sustainable management and use of natural resources, sustainable production and consumption, a better environment for human health and well-being, and globalisation trends and the environment. ${ }^{70}$

The Rio Conference advocated an expanded mandate and a more active role for UNEP. In Agenda 21, which is the most important document of the Conference, it is stated that:

"In the follow-up to the Conference, there will be a need for an enhanced and strengthened role for UNEP and its Governing Council. The Governing Council should, within its mandate, continue to play its role with regard to policy guidance and co-ordination in the field of environment taking into account the development perspective." ${ }^{71}$

\footnotetext{
${ }^{68}$ Cf. ThaCher, p. 191.

${ }^{69}$ Caldwell, p. 72.

${ }^{70} 18$ International Environment Reporter (June 1995) 451.

${ }^{71}$ Agenda 21, Chapter 38, para. 21.
} 
The development perspective of environmental measures and the environmental aspects of development policies, which have been UNEP's real challenge since its inception, constitute the core of the concept of sustainable development. This concept, with its emphasis on the need for a balance between economic development and preservation of the environment for the present and future generations, found definitive political endorsement by over a hundred heads of government and state in Rio. As one of the results of this high-level political recognition of the need for integration of environment and development and the complementarity of these two processes, the Conference decided to establish a special Commission for Sustainable Development (CSD). The main purpose of this Commission is to ensure an effective follow-up of the Conference, to strengthen international co-operation, and to rationalise the intergovernmental decisionmaking processes with respect to the integration of environment and development as well as to follow up the implementation of Agenda $21 .^{72}$ The CSD's terms of reference presage a close and special relation between this new organ and UNEP.

Finally, mention should be made of UNEP's close relation with a broad range of non-governmental organisations. The contacts between these organisations and specialised agencies or UN subsidiary organs are not unprecedented, but the nature of UNEP's work requires closer contacts with nongovernmental organisations. Of particular importance is the relation between UNEP on the one hand, and IUCN (now World Conservation Union), WWF, ICSU, Friends of the Earth and Greenpeace on the other. These, as well as some other non-governmental organisations, have regular communication with UNEP's Liaison Offices in Nairobi and New York.

\section{UNEP AND THE DEVELOPMENT OF INTERNATIONAL ENVIRONMENTAL LAW}

UNEP did not receive any explicit mandate in Resolution 2997 (XXVII) to work for the development of international environmental law. However, it was argued that the General Assembly had there given its own authority to UNEP "to promote international co-operation in the field of environment", ${ }^{73}$ and in delegating this authority the General Assembly arguably

\footnotetext{
${ }^{72}$ Ibid., Chapter 38, para. 11. The CSD was established according to Article 68 of the UN Charter.

${ }^{73}$ UNGA Resolution 2997 (XXVII), part I, para. 2(a).
} 
had drawn on its own authority to encourage the progressive development of international law. Thus, the Governing Council received authority to promote the development of international environmental law, and it draws on this authority when it requests the Executive Director to develop conventions and guidelines. ${ }^{74}$

Agenda 21 transformed UNEP's de facto competence in international environmental law into an explicit authority. Accordingly, UNEP shall concentrate its efforts to:

\begin{abstract}
"further development of international environmental law, in particular conventions and guidelines, promotion of its implementation, and coordinating functions arising from an increasing number of international legal agreements, inter alia, the functioning of the secretariats of the Conventions, taking into account the need for the most efficient use of resources, including possible co-location of secretariats established in the future." 75
\end{abstract}

The lack of explicit competence in the field of environmental law was the main reason for rather disorganised measures by UNEP during its first ten years. Aware of this problem, the Executive Director at the request of the Governing Council assigned a special working group of Senior Government Officials Expert in Environmental Law to work out a plan for the development of environmental law. The result of the work of this group was adopted in 1982 under the title of Montevideo Programme. ${ }^{76}$ This programme called for development of the law in three major subject areas, namely, land-based marine pollution, protection of the stratospheric ozone layer, and the transport, handling and disposal of toxic and dangerous wastes. ${ }^{77}$ In addition, eight other areas were identified which should in the second place be target for legal development: environmental emergencies, coastal zone management, soil conservation, transboundary air pollution, international trade in potentially harmful chemicals, prevention of pollution of rivers and other inland waters, legal and administrative mechanisms for the prevention and redress of pollution damage, and environmental impact assessment. ${ }^{78}$ The Montevideo Programme working group concluded that

\footnotetext{
74 Petsonk, p. 355.

${ }^{75}$ Agenda 21, Chapter 38, para. 22(h).

${ }^{76}$ The Montevideo Programme for the Development and Periodic Review of Environmental Law, in H. HoHmanN, Basic Documents of International Environmental Law, Vol. I (Graham \& Trotman/Martinus Nijhoff, 1992) pp. 70-78.

${ }^{77}$ Ibid., part II, section I.

${ }^{78}$ Ibid., part II, section II.
} 
guidelines, principles and conventions should be developed in the three major subject areas. Besides, action should be taken in accordance with the programme's strategies for the other eight subject areas. Finally, according to the working group, the work of UNEP in the development of environmental law should be promoted. ${ }^{79}$ The Montevideo Programme was revised in 1992 by a group of experts from 81 countries, and this revised programme was adopted by the UNEP Governing Council in May 1993. ${ }^{80}$ The areas named in the programme concern principles, substantive matters, and institutional matters. UNEP's environmental law activities since 1982 generally follow the Montevideo Programme.

In addition to the very important assistance to developing countries in shaping their own environmental legislation, UNEP's contribution to the development of international environmental law normally takes the form of guidelines, action plans and conventions. Adoption of such documents usually starts by seeking scientific consensus on an environmental problem. The next step is the development of a legal strategy by legal-technical working groups which review draft legal texts prepared by UNEP's Environmental Law Unit. All states may participate in these groups. Once the legal and technical issues are more or less settled, UNEP tries to consolidate political support for the planned measures against the environmental problem. The text of a guideline, adopted by consensus by the legal-technical working group, is sent to the Governing Council for possible adoption. Guidelines are not legally binding, but they very often find expression in national laws or other binding documents. If the text adopted by the working group is a draft convention and there is enough political support for it, a diplomatic conference will be convened for the formal adoption of the convention. ${ }^{81}$ The greater part of the law-making efforts of UNEP is devoted to guidelines and action plans. In some cases, a next step will be to proceed with the work for adopting a convention on the basis of the guidelines and action plans. However, these 'soft-law' documents have the advantage of avoiding the controversies about scientific uncertainty or economic implications of the proposed measures. ${ }^{82}$

UNEP's guidelines concern completely different subjects. So far over 10 such guidelines have been adopted, including guidelines on shared natural resources (1973), co-operation in weather modification (1980),

\footnotetext{
79 UNEP's Conclusions and Recommendations of Montevideo, 1981, 2(a), (b) and (c), in HoHMANN, Vol. 1, p. 69.

${ }^{80}$ UNEP/GC. 17/5 (1993).

${ }^{81}$ PETSONK, pp. 365-366.

82 BIRNIE, p. 351.
} 
offshore mining and drilling (1982), land-based pollution of the marine environment (1985), management of hazardous waste (1987), environmental impact assessment (1987) and exchange of information on chemicals in international trade (1989) ${ }^{83}$ The language of these guidelines is permissive and vague, clearly showing the intention of the drafters not to imply any legal obligation. As regards action plans, the 1984 Action Plan for Biosphere Reserves, ${ }^{84}$ together with several other international documents, led to the adoption of the 1992 Convention on Biological Diversity.

UNEP has drafted, negotiated and obtained adoption for a number of important conventions in international environmental law. Here, a distinction should be made between agreements adopted within the framework of UNEP's Regional Seas Programme and international agreements in other fields of environmental law. The Regional Seas Programme contains regional conventions for the protection of marine environments. ${ }^{85}$ Inspired by the 1974 Convention for the Protection of the Baltic Sea (Helsinki Convention), one of the first steps taken by UNEP was to invite in 1975 the coastal states around the Mediterranean to adopt the Mediterranean Plan of Action. This was a non-binding document, which became the basis for the adoption of the Barcelona Convention for the Protection of the Mediterranean Sea against Pollution in 1976. This Convention, like the Helsinki Convention, has a holistic approach to marine environmental problems. The adoption of the Barcelona Convention gave rise to what is coined as the 'Barcelona process'. The characteristic of this process is that a number of states with broadly disparate interests agree first on a non-binding instrument, and later make that agreement legally binding in a framework convention. The ambiguous language of the framework convention permits a greater number of states to become parties, with the option of undertaking specific obligations under the protocols appended to the convention. ${ }^{86}$ The Barcelona process was effectively applied in the adoption of a range of conventions for different regional seas, all with the same holistic approach

\footnotetext{
${ }^{83}$ For the text of these documents, see HoHMANN, Vol. 1, pp. 54-190.

84 UNEP/GC. 13/L.6.

${ }^{85}$ These conventions, in contradistinction to other legal documents which are prepared by UNEP's Environmental Law Unit, are worked out by the Ocean and Coastal Areas Programme Activity Centre (OCAPAC).

${ }^{86}$ PETSONK, pp. 365-366. Five different protocols on different types of marine pollution in the Mediterranean have been adopted. The parties to the Barcelona Convention have to join at least one of these protocols. For discussion on the Convention and its protocols, see P. SAND, Marine Environment Law in the United Nations Environment Programme, UNEP, 1988.
} 
to environment problems. ${ }^{87}$ The adoption of these regional conventions has always been facilitated by the fact that marine pollution, as against other environmental nuisance, is the most tangible problem, with direct and immediate undesirable effects. States have always given priority to the combat against marine pollution.

Different from the regional seas conventions are the conventions which UNEP has so far worked out in other areas where states have had varying degrees of enthusiasm and devotion. The first was the 1985 Vienna Convention for the Protection of the Ozone Layer. ${ }^{88}$ The Vienna Convention was adopted further to the decisions in the Montevideo Programme, and, building on the Barcelona model, was followed by the Montreal Protocol on Substances that deployed the Ozone Layer. ${ }^{89}$ However, in contrast to the Barcelona process, the Convention was not preceded by a non-binding document. The Convention and its Protocol, which have been amended a couple of times, are generally considered as most important documents in international environmental law. The reason is that so many countries have for the first time agreed to take concrete measures on an important environmental problem, and have in fact done so. This is particularly important because, despite negative economic implications of the adopted measures for both developing and developed countries, the Convention has succeeded in its objectives in the relatively very short time which has elapsed since its adoption. Even recalcitrant states such as India and China have ratified the Montreal Protocol.

Another result of UNEP initiative is the important 1989 Basel Convention on the Control of Transboundary Movement of Hazardous Wastes and their Disposal..$^{90}$ The adoption of this Convention was preceded by the 1985 UNEP Cairo Guidelines and Principles for the Environmentally Sound Management and Disposal of Hazardous Wastes. ${ }^{91}$ The negotiations did

\footnotetext{
${ }^{87}$ These conventions and related protocols are for the protection of the marine environment in the Persian Gulf (1978, given in 17 ILM, p. 511), West and Central African Region (1981, 20 ILM, p. 746), the Southeast Pacific (1981, SAND, ibid., p. 84), Red Sea and Gulf of Aden (1982, SAND, ibid., p. 114), the Caribbean Sea (1983, 22 ILM, p. 227), East Africa (1985, HohmanN, Vol. 2, p. 1032), the South Pacific (1986, HohmanN, Vol. 2, p. 1060) and Zambezi River Basin (1987, 27 ILM, p. 1112). In addition, an action programme for the protection of the Marine and Coastal Environment of the Northwest Pacific Region (NOWPAR) was adopted on 14 September 1994.
}

${ }^{88} 25$ ILM, p. 1370.

${ }^{89} 26$ ILM, p. 1541.

${ }^{90} 28$ ILM, p. 657.

${ }^{91}$ HohmanN, Vol. 1, p. 148. 
not then achieve a total ban of export of hazardous wastes because waste traffic was of economic significance, but a later review conference did. ${ }^{92}$

UNEP's intensive involvement in environmental impact assessment and its pressure for an international agreement on this subject led to the adoption of the 1991 Convention on Environment Impact Assessment. ${ }^{93}$ One of the two major conventions adopted at the Rio Conference, the Convention on Biological Diversity, was also prepared by UNEP. ${ }^{94}$ This is a framework and comprehensive convention which has taken particular account of the economic dimensions of biological resources and their management.

Finally, mention should be made of another role of UNEP relative to the implementation of international environmental law. UNEP serves as secretariat for a number of important international conventions including the 1985 Vienna Convention for the Protection of the Ozone Layer and its Montreal Protocol, the Convention on International Trade in Endangered Species of Wild Fauna and Flora (CITES), ${ }^{95}$ and the Convention on the Conservation of Migratory Species of Wild Animals. ${ }^{96}$ The secretariats of these conventions have legal status independent from UNEP. UNEP is not party to any convention, and does not have any legal relationship with these secretariats except where a convention, pursuant to the consent of UNEP, expressly provides rights and obligations for it. By exercising its co-ordination function, UNEP contributes to the effective implementation of the conventions and better operation of the secretariats. ${ }^{97}$

\footnotetext{
${ }^{2}$ For a detailed discussion on the role of UNEP in the preparation and negotiation of this convention, see, K. KUMMER, 'The International Regulation of Transboundary Traffic in Hazardous Wastes: The 1989 Basel Convention', 41 International and Comparative Law Quarterly (1992) p. 530; PETSONK, pp. 374-381.

${ }_{93}$ This convention was prepared by the Economic Commission for Europe, but it was indeed thanks to UNEP's active involvement both through its 1987 guideline on goals and principles of environmental impact assessment and recommendation of senior advisers to the Executive Director, that its adoption became possible. Cf. PETSONK, p. 358.

${ }^{94}$ The Governing Council's decision on the preparation for an international legal instrument on the biological diversity of the planet (15/34) was adopted on 25 May 1989.

9512 ILM, p. 1085.

96 ILM, p. 15.

${ }^{97}$ Cf. A. Timoshenko, 'International Environmental Law in the Post-UNCED Era', paper presented at the International Law Association's 66th Conference, Buenos Aires, 14-20 August 1993, p. 5.
} 


\section{CONCLUSION}

Chapter 39 of Agenda 21 introduced the concept of "international law of sustainable development". Even if no definition is given for this concept, the content of Chapter 39 implies that this concept overlaps with international environmental law. One corollary of such an overlap or equation is that environmental law today should be viewed in the wider context of sustainable development. ${ }^{98}$ This in itself requires due consideration in lawmaking of integration of environment and development. Given the impressive results of UNEP's activities in the last two decades, particularly its continuous efforts for integration of environment and development and its role in attracting the confidence and active participation of many developing countries in international environmental arrangements, it was only natural that Agenda 21 entrusted it with an expanded mandate for the development of international law of sustainable development and for effective implementation of adopted measures.

As a subsidiary organ of the General Assembly with a tiny budget never enough for its ambitious programmes, UNEP has suffered from the traditional administrative constraints of such organs. However, the dynamism of its mandate, the increasing interest and involvement of the public in environmental issues, energetic leadership, and a rather small but professional staff have together resulted in achievements not normally possible even for larger organisations with larger budgets. Hardly any other UN subsidiary organ can be compared with UNEP in this respect. UNEP has been a big soul in a little body. ${ }^{99}$

UNEP has emerged from its teething troubles and now has the necessary experience to act with more authority and independence without risking entanglement in the bureaucratic routines of specialised agencies. Promotion from subsidiary organ to specialised agency would afford it the necessary power to fulfil its expanded task, particularly with respect to the development of international law, and supervision of the implementation of international legal agreements. One important corollary of such elevated status would be the ability to request advisory opinions from the International

\footnotetext{
98 Ibid., p. 3.

${ }^{99}$ One established view is that the term 'subsidiary organ' is essentially a formal one, and does not necessarily imply any measure of the autonomy such an organ enjoys vis-à-vis the principal organ. SIMMA, p. 196. However, a careful study of the situation in UNEP and even in UNDP shows that this 'formal' relation has implied a range of limitations particularly with respect to financing. Specialised agencies normally do not experience the limitations in the same way.
} 
Court of Justice. Many important questions in environmental law still need legal clarification by an international legal authority such as the ICJ. One such question is the right to a decent environment as a human right. Another corollary would be increased activity by UNEP in preparing more international binding instruments, particularly in areas not specifically within the competence of other UN bodies. International trade in chemicals and land-based marine pollution have been named as two such areas.

Notwithstanding the resistance of some countries, the nature of environmental issues and the global relevance of related problems dictate that the United Nations give proper priority to the environmental item on its agenda. Such a priority requires a status for UNEP at least equal to that of UNESCO, ILO or IMO. One possible occasion for this elevation will arise at the turn of the century, when the results of the national implementation of Agenda 21 are to be assessed by the UN. 